\title{
On the barium - oxygen consumption relationship in the Mediterranean Sea: implications for mesopelagic marine snow remineralisation
}

STÉPHANIE JACQUET, DOMINIQUE LEFEVRE, CHRISTIAN TAMBURINI, MARC GAREL AND FREDERIC LE MOIGNE

Mediterranean Institute of Oceanography

Presenting Author: stephanie.jacquet@mio.osupytheas.fr

In the ocean, remineralisation rate associated with sinking particles is a crucial variable. Since the 90's, particulate biogenic barium $\left(\mathrm{Ba}_{\mathrm{xs}}\right)$ has been used as an indicator of carbon remineralization by applying a transfer function relating $\mathrm{Ba}_{\mathrm{xs}}$ to $\mathrm{O}_{2}$ consumption (Dehairs's transfer function, Southern Oceanbased). Here, we tested its validity in the Mediterranean Sea (ANTARES / EMSO-LO) for the first time by investigating connections between $\mathrm{Ba}_{\mathrm{xs}}$, prokaryotic heterotrophic production (PHP) and oxygen consumption $\left(\mathrm{JO}_{2}-\mathrm{Opt} ;\right.$ optodes measurement). We show that: (1) higher $\mathrm{Ba}_{\mathrm{xs}}(409 \mathrm{pM} ; 100-500$ $\mathrm{m}$ ) occurs in situations where integrated PHP (PHP100/500= 0.90) is located deeper, (2) higher $\mathrm{Ba}_{\mathrm{xs}}$ occurs with increasing $\mathrm{JO}_{2}$-Opt, and (3) similar magnitude between $\mathrm{JO}_{2}$-Opt (3.14 mmol $\left.\mathrm{m}^{-2} \mathrm{~d}^{-1} ; 175-450 \mathrm{~m}\right)$ and $\mathrm{JO}_{2}-\mathrm{Ba}\left(4.59 \mathrm{mmol} \mathrm{m}^{-2} \mathrm{~d}^{-1}\right.$; transfer function). Overall, $\mathrm{Ba}_{\mathrm{xs}}$, $\mathrm{PHP}$ and $\mathrm{JO}_{2}$ relationships follow trends observed earlier in the Southern Ocean. We conclude that such transfer function could apply in the Mediterranean Sea. 